\title{
Concanavalin A Amplifies both $\beta$-Adrenergic and Muscarinic Cholinergic Receptor-Adenylate Cyclase-linked Pathways in Cardiac Myocytes
}

\author{
Krishna J. Rocha-Singh, Dawn K. Hines, Norman Y. Honbo, and Joel S. Karliner \\ Cardiology Section, Department of Veterans Affairs Medical Center, Cardiovascular Research Institute; and Division of Clinical \\ Pharmacology and Experimental Therapeutics, University of California, San Francisco, California 94121
}

\begin{abstract}
Concanavalin A (Con A) is a tetrameric plant lectin that disrupts plasma membrane-cytoskeletal interactions and alters plasma membrane fluidity. We used Con $A$ as a probe to explore $\beta$-adrenergic and muscarinic cholinergic receptor-mediated regulation of $\mathrm{CAMP}$ in intact neonatal rat ventricular myocytes. Preincubation with Con $A, 0.5 \mu \mathrm{g} / \mathrm{ml}$, attenuated 1 $\mu \mathrm{M}(-)$-norepinephrine (NE)-induced downregulation of $\beta$ adrenergic receptors and resulted in a $50 \%$ augmentation of cAMP accumulation stimulated by $1 \mu M$ NE. Con $A$ also augmented forskolin (1-10 $\mu \mathrm{M})$-stimulated cAMP accumulation by an average of $37 \%(P<0.05)$; however, Con $A$ preincubation had no effect on basal or cholera toxin-stimulated CAMP content. The muscarinic cholinergic agonist carbachol (1-100 $\mu \mathrm{M})$ decreased $1 \mu M$ NE-stimulated cAMP generation by an average of $32 \%(n=7, P<0.05)$; preincubation with $C$ on $A$ further enhanced the inhibitory effect of carbachol by $18 \%(n=7, P$ $<0.05)$. Carbachol ( $1 \mu M$ ) for 2 h decreased muscarinic cholinergic receptor density in whole cells by $33 \%$; preincubation with Con A prevented this receptor downregulation. Con A pretreatment did not affect (-)-isoproterenol- or forskolin-stimulated adenylate cyclase activity in cell homogenates, suggesting that an intact cytoarchitecture is necessary for Con A to augment cAMP formation.

We conclude that Con A, through its modulation of $\beta$ adrenergic and muscarinic cholinergic receptor signaling, amplifies both stimulatory and inhibitory adenylate cyclase-linked pathways in intact neonatal ventricular myocytes. These data suggest the possibility that plasma membrane-cytoskeletal interaction is an important regulator of transmembrane signaling because interference with this interaction results in alterations in cAMP accumulation mediated by both $\beta$-adrenergic- and muscarinic cholinergic-adenylate cyclase pathways. ( $J$. Clin. Invest. 1991. 88:760-766.) Key words: concanavalin A - cytoskeleton $\bullet \beta$-adrenergic receptor $\bullet$ muscarinic cholinergic receptor $\bullet$ cAMP • adenylate cyclase
\end{abstract}

\section{Introduction}

The adenylate cyclase system, which mediates cellular responses to a variety of hormones and neurotransmitters, is composed of three distinct components that interface with the in-

Address correspondence and reprint requests to Dr. Joel S. Karliner, Cardiology Section (111C), Veterans Affairs Medical Center, 4150 Clement Street, San Francisco, CA 94121.

Received for publication 3 August 1989 and in revised form 19 March 1991.

The Journal of Clinical Investigation, Inc.

Volume 88, September 1991, 760-766 ner surface of the plasma membrane: the hormone receptor, the guanine nucleotide-binding proteins (G-proteins) and the catalytic unit (1). Recent evidence suggests that these components also interact with the cytoskeleton, a highly complex array of microtubules and microfilaments that provide the cell with shape, motility, and internal spatial organization (2-6). Although it is well established that these cytoskeletal elements can regulate the functional properties of the plasma membrane $(7,8)$, the potential mechanism(s) were, until recently, poorly defined. Current evidence suggests that both membrane-associated components of adenylate cyclase-linked pathways and cytoskeletal elements are substrates for protein kinase-mediated phosphorylation, which may modulate coupling to their effector systems (9-13). Thus, plasma membrane-cytoskeletal interactions may be important participants in the regulation of transmembrane signaling and thereby directly affect cellular responses to external stimuli $(14,15)$.

In myocardial cells there is little information regarding the possible regulatory role of the plasma membrane-cytoskeletal complex and adenylate cyclase-linked signal transduction. Concanavalin A (Con A), ${ }^{1}$ a tetrameric lectin derived from the jack bean, Cancanvalia ensiformis, binds to specific membrane receptors $(16,17)$, increases plasma membrane fluidity (18), and may perturb plasma membrane-cytoskeletal relations (16). In this study we explored the effects of Con A on components of the $\beta$-adrenergic- and muscarinic cholinergic-adenylate cyclase system in intact neonatal rat ventricular myocytes. Our results suggest the possibility that both alterations in membrane fluidity and in plasma membrane-cytoskeletal interactions are important regulators of transmembrane signaling because both stimulatory and inhibitory pathways coupled to adenylate cyclase appear to be dependent on such interactions. Furthermore, the maintenance of an intact cellular architecture appears to be an important prerequisite to cytoskeletal modulation of transmembrane signaling.

\section{Methods}

Ventricular myocardial cell preparation. Primary cell cultures were composed of single isolated ventricular myocytes prepared from hearts of 1-d-old rats as previously described (19). Cells obtained by brief alternating cycles of room temperature trypsinization and mechanical dissociation were washed and preplated with $5 \%$ bovine calf serum to reduce the number of contaminating nonmyocardial cells. After 30 min nonattached myocardial cells were removed, counted, and diluted in culture medium containing $5 \%$ bovine calf serum and plated at a density of $\sim 380$ cells per $\mathrm{mm}^{2}$ into 100 -mm plastic dishes (Falcon; Becton Dickinson and Co., Mountain View, CA) or $8.6 \times 10^{4}$ cells/well into 24-well culture plates (Falcon) for cAMP assay. The standard

1. Abbreviations used in this paper: Con A, concanavalin $\mathrm{A}$; Gpp(NH)p, guanyl-5'-imidodiphosphate; MNP, mannopyranoside; $\mathrm{NE},(-)$-norepinephrine. 
serum-free medium was MEM with Hanks' salt solution supplemented with $1.5 \mu \mathrm{M}$ vitamin $B_{12}$ and $50 \mathrm{U} / \mathrm{ml}$ penicillin. Through day 3 the medium contained $0.1 \mathrm{mM}$ bromodeoxyuridine to prevent low level nonmyocardial cell proliferation as previously described (19). Medium was routinely changed on day 4 .

Cell yield was 5-7 million per heart of which $\sim 90 \%$ were viable. All cultures were kept at $37^{\circ} \mathrm{C}$ in humidified air with $1 \% \mathrm{CO}_{2}$ to maintain $\mathrm{pH}$ 7.3. The cultures contained $>90 \%$ myocardial cells and cell numbers were constant over time.

Con A was dissolved in sterile double-distilled water to a stock concentration of $5 \mathrm{mg} / \mathrm{ml}$. (-)-Norepinephrine was dissolved in $1 \mathrm{mM}$ $\mathrm{HCl}$; forskolin was dissolved in DMSO to a final concentration of $0.1 \%$, which did not alter cAMP levels. All other drugs, carbachol, cholera toxin, and guanosine 5 '-triphosphate (GTP) were dissolved in doubledistilled water. All experiments were performed in intact cells preincubated for 30 min in Hanks' medium supplemented with $5 \%$ bovine calf serum containing $1 \mathrm{mM}$ 3-isobutyl-1-methylxanthine (IBMX), a phosphodiesterase inhibitor.

Radioligand binding studies. Radioligand binding studies were carried out on days 5-7 after plating. Cells were incubated with reagents (Con A, (-)-norepinephrine, carbachol) for designated time periods (see Results). Myocardial cells were prepared for radioligand binding studies by rapid washing with $5 \mathrm{ml}$ of the following "CGP buffer": $153 \mathrm{mM} \mathrm{NaCl}, 10 \mathrm{mM}$ Tris- $\mathrm{HCl}, 5 \mathrm{mM} \mathrm{MgCl} 2, \mathrm{pH} \mathrm{7.4,} \mathrm{or} \mathrm{"musca-}$ rinic buffer": $110 \mathrm{mM} \mathrm{NaCl}, 5.3 \mathrm{mM} \mathrm{KCl}, 1.8 \mathrm{mM} \mathrm{CaCl}, 1.0 \mathrm{mM}$ $\mathrm{MgCl}_{2}, 25 \mathrm{mM}$ glucose, $20 \mathrm{mM}$ Hepes ( $N$-2-hydroxyethylpiperazine$N$-2-ethanesulfonic acid), pH adjusted to 7.4 with $\mathrm{HCl}$. Both harvesting buffers contained $0.65 \mathrm{mU}$ aprotinin, a protease inhibitor. Cells were immediately harvested using a plastic spatula and suspended in the appropriate ice-cold buffer. Cell aggregation in this suspension was minimized by three gentle strokes in a glass homogenizing tube and filtration through a single layer of 110 mesh nylon gauze (Nitex, Switzerland). Preliminary experiments documented $>80 \%$ trypan blue exclusion using this method.

The cell suspension was then incubated with $(+)-\left[{ }^{3} \mathrm{H}\right] 4-(3-t-b u t y l-$ amino-2-hydroxypropoxy)benzimidazol-2-one hydrochloride $\left({ }^{3} \mathrm{H}\right.$ CGP-12177) $(0.5-15.0 \mathrm{nM})$ or ${ }^{3} \mathrm{H}$-methyl-scopolamine $(0.2-20 \mathrm{nM})$ in a total volume of $0.5 \mathrm{ml}$ at $37^{\circ} \mathrm{C}$ for $30 \mathrm{~min}$ in $12 \times 75-\mathrm{mm}$ polypropylene tubes. Nonspecific binding was determined using $1 \mu \mathrm{M}(-)$-propranolol or $1 \mu \mathrm{M}$ atropine, respectively. The binding reaction was terminated by adding $5 \mathrm{ml}$ ice-cold CGP buffer or ice-cold $50 \mathrm{mM}$ Tris $\mathrm{HCl}, \mathrm{pH} 7.5$, followed by immediate filtration through glass fiber filters (Whatman GF/C; Whatman Inc., Clifton, NJ) using a Brandel Cell Harvester (Brandel Laboratories, Gaithersburg, MD). Retained radioactivity was determined $24 \mathrm{~h}$ after addition of $7 \mathrm{ml}$ of scintillation fluid (Cytoscint; WestChem, San Diego, CA) in a scintillation counter (Model LS 350; Beckman Instruments, Inc., Fullerton, CA) with an efficiency of $36 \%$. Specific binding was defined as the difference between total binding and nonspecific binding and ranged from $65-80 \%$ for both ${ }^{3} \mathrm{H}$-CGP-12177 and ${ }^{3} \mathrm{H}$-methyl-scopolamine. All determinations were performed in duplicate.

Equilibrium binding studies using ${ }^{125}$ I-iodocyanopindolol (ICYP) were performed in triplicate in a particulate preparation as described below (20). Nonspecific binding was determined using $1 \mu \mathrm{M}(-)$-propranolol; specific binding ranged from 75 to $93 \%$. For both radioligands, the maximum number of binding sites $\left(B_{\max }\right)$ and the equilibrium $K_{\mathrm{d}}$ were determined by least squares linear regression analysis using the method of Scatchard (21). Six to eight points were measured for each determination of $B_{\max }$. Protein was measured by the method of Lowry et al. (22), using bovine serum albumin as standard.

For construction of (-)-isoproterenol competition curves and adenylate cyclase determinations, cardiac myocyte membranes were prepared by washing cells three times with $1 \mathrm{mM}$ Tris-HCl/2 mM EGTA buffer, pH 7.4, with subsequent in situ lysis for $30 \mathrm{~min}$ at $4^{\circ} \mathrm{C}$, as previously described (20). This particulate preparation was harvested using a plastic spatula and placed in $18 \times 100$ - $\mathrm{mm}$ polycarbonate tubes and centrifuged at $40,000 \mathrm{~g}$ for $30 \mathrm{~min}$ at $4^{\circ} \mathrm{C}$. The pellet was resus- pended in $1 \mathrm{ml} 0.25 \mathrm{M}$ sucrose $/ 5 \mathrm{mM}$ Tris- $\mathrm{HCl} / 1 \mathrm{mM}$ EDTA buffer, $\mathrm{pH}$ 7.4. This membrane preparation was resuspended in $50 \mathrm{mM}$ Tris $\mathrm{HCl} / 1 \mathrm{mM} \mathrm{MgCl} 2, \mathrm{pH} 7.4$ (incubation buffer), at a concentration of $0.2-0.3 \mathrm{mg} / \mathrm{ml}$ after filtration through Nitex gauze; $0.08 \mathrm{ml}$ of this membrane preparation was incubated with $0.01 \mathrm{ml}^{125} \mathrm{I}-\mathrm{ICYP}$ at a final concentration of $20 \mathrm{pM}$ and $0.01 \mathrm{ml}$ (-)-isoproterenol, at final concentrations ranging from $1 \mathrm{nM}$ to $10 \mathrm{mM}$, in a total volume of $0.1 \mathrm{ml}$ at $37^{\circ} \mathrm{C}$ for $30 \mathrm{~min}$, in $12 \times 75$-mm polypropylene tubes. Binding reactions were terminated by the addition of $10-15 \mathrm{ml}$ ice-cold $50 \mathrm{mM}$ Tris- $\mathrm{HCl}$ and $10 \mathrm{mM} \mathrm{MgCl}_{2}$ buffer, $\mathrm{pH} 7.4$, and the contents immediately filtered through glass fiber filters (Whatman GF/C) and counted in a gamma counter (Beckman 8500 ) with a $73 \%$ counting efficiency. All determinations were carried out in triplicate.

Adenylate cyclase assay. Adenylate cyclase activity was determined by a modification of the method of Ramachandran (23) as previously reported (method No. 1) (24). Briefly, the assay mixture contained, in a final volume of $200 \mu 1,0.083 \mathrm{mM}\left[\alpha^{3}{ }^{32} \mathrm{P}\right] \mathrm{ATP}\left(1-2 \times 10^{5} \mathrm{cpm}\right), 1.7$ $\mathrm{mM} \mathrm{MgCl} 2,0.33 \mathrm{mM}$ cAMP, $0.42 \mathrm{mM}$ Tris-Hepes buffer ( $\mathrm{pH}$ 7.5), 4.2 $\mathrm{U}$ creatine kinase, $11 \mathrm{mM}$ phosphocreatine, and $60-120 \mu \mathrm{g}$ of protein. Incubations were carried out at $30^{\circ} \mathrm{C}$ for $30 \mathrm{~min}$ and the results obtained were linear with time and protein concentration. To terminate the reaction, $580 \mu \mathrm{l}$ of a stopping solution $\left(10-16,000 \mathrm{cpm}{ }^{3} \mathrm{H}-\mathrm{cAMP}\right.$ in $0.345 \mathrm{~N} \mathrm{HCl}$ ) was added to each tube. Then $220 \mu \mathrm{l}$ of $1 \mathrm{M}$ Tris base was added and the samples were centrifuged at $2,500 \mathrm{rpm}$ for $10 \mathrm{~min}$ in a Sorvall RT 6000B (DuPont Co., Wilmington, DE). The supernatant was passed over a disposable column containing $1.5 \mathrm{~g}$ fresh, dry neutral alumina AG7 (Bio-Rad Laboratories, Richmond, CA). The column was eluted with $3 \mathrm{ml}$ Tris- $\mathrm{HCl}, \mathrm{pH} 7.5$, and the eluent was collected and counted in $12 \mathrm{ml}$ of Universol (WestChem). Recovery of added ${ }^{3} \mathrm{H}$ cAMP was $90-95 \%$.

During the course of this study a further modification of this assay procedure as described by Alvarez and Daniels (24a) was used (method No. 2). This modification was used for experiments examining (-)-isoproterenol-mediated activation of adenylate cyclase. Samples were incubated in boiling water for $4 \mathrm{~min}$ rather than centrifuged and columns containing $2.6 \mathrm{~g}$ neutral alumina were eluted with $5 \mathrm{ml} 0.1 \mathrm{M}$ ammonium acetate instead of Tris- $\mathrm{HCl}$. Using this approach background counts were virtually zero.

cAMP radioimmunoassay. Intracellular cAMP accumulation was determined using a modification of the procedure described by Steiner et al. (25). Briefly, 5-7-d-old myocardial cells plated in 24-well culture dishes (Falcon) were preincubated with (-)-norepinephrine, forskolin, or carbachol in the presence or absence of Con A. Immediately after incubation with agonist in the presence of $1 \mathrm{mM}$ IBMX, medium was aspirated and cells were eluted with $3 \mathrm{ml}$ of $95 \%$ ethanol. The eluent was transferred to $12 \times 75-\mathrm{mm}$ borosilicate glass tubes, air dried, and stored at $4^{\circ} \mathrm{C}$ for up to $1 \mathrm{mo}$, which did not affect the results. At the time of assay the pellet was brought to room temperature and resuspended in $0.3 \mathrm{ml} 0.05 \mathrm{M} \mathrm{NaOAC}, \mathrm{pH} 6.2 ; 0.1 \mathrm{ml}$ of this resuspension or $0.1 \mathrm{ml}$ of cAMP standard was added to $0.1 \mathrm{ml}$ of ${ }^{125}$ I-succinyl-cAMP tyrosine methyl ester tracer (6-12,000 cpm). $100 \mu$ l of goat cAMP antibody in sodium acetate buffer containing $2 \mathrm{mg} / \mathrm{ml}$ bovine gamma globulin was then added in a final dilution of 1:240,000 and incubated overnight on ice; $1.5 \mathrm{ml}$ polyethylene glycol(PEG)-gamma globulin solution ( $160 \mathrm{mg}$ PEG per $\mathrm{ml} 1 \%$ bovine gamma globulin solution) was added to each tube and the precipitated antibody-antigen complex centrifuged at $40,000 \mathrm{rpm}$ (Sorvall TB3500) for $40 \mathrm{~min}$. After aspiration of the supernatant from this spin, the ${ }^{125} \mathrm{I}$-antigen-antibody complex was counted for 1 min in a gamma counter (Beckman 8500) with an efficiency of $73 \%$.

Data analysis. Results are expressed as mean \pm SEM and were compared using Student's $t$ test for paired data; a $P$ value of $<0.05$ was considered significant.

Materials. Concanavalin A, (-)-norepinephrine, (-)-isoproterenol, forskolin, carbachol, IBMX, guanyl-5'-imidodiphosphate (Gpp(NH)p), GTP, ATP, creatine kinase, phosphocreatine, sucrose, ammonium acetate, and methyl $\alpha$-D-mannopyranoside were from 
Sigma Chemical Co., St. Louis, Missouri; ${ }^{3} \mathrm{H}-\mathrm{CGP}-12177$ (30-35 Ci/ $\mathrm{mmol}),{ }^{3} \mathrm{H}$-methyl-scopolamine $(80-85 \mathrm{Ci} / \mathrm{mmol})$ and ${ }^{125} \mathrm{I}-\mathrm{ICYP}$ $(2,200 \mathrm{Ci} / \mathrm{mmol})$ were from New England Nuclear, Boston, MA. Cholera toxin was from List Biological Laboratories, Campbell, CA: (-)propranolol was a generous gift from Ayerst Laboratories, Inc., New York. Goat cAMP antibody used for the cAMP-RIA was a gift from Dr. Hunter Heath, Rochester, MN.

\section{Results}

Concanavalin A inhibits agonist-induced $\beta$-adrenergic and muscarinic cholinergic receptor downregulation. We initially determined the effect of Con A on homologous regulation of the $\beta$-adrenergic receptor. Incubation of intact neonatal rat ventricular myocytes with $1 \mu \mathrm{M}(-)$-norepinephrine $(\mathrm{NE})$ for $2 \mathrm{~h}$ resulted in a $41 \%$ decrease in cell surface $\beta$-adrenergic receptor density using the hydrophilic radioligand ${ }^{3} \mathrm{H}-\mathrm{CGP}-12177$ (Fig. 1). $K_{d}$ values in the control cells averaged $0.67 \pm 0.15 \mathrm{nM}$ and were not significantly different from the NE-treated cells. Preincubation with Con A $0.5 \mu \mathrm{g} / \mathrm{ml}$ for $30 \mathrm{~min}$ before NE exposure attenuated this agonist-induced $\beta$-adrenergic receptor downregulation. Con A alone had no effect on cell surface receptor density; however, it did substantially increase antagonist affinity by $61 \%$, from $0.67 \pm 0.15$ to $1.7 \pm 0.19 \mathrm{nM}(P<0.025)$
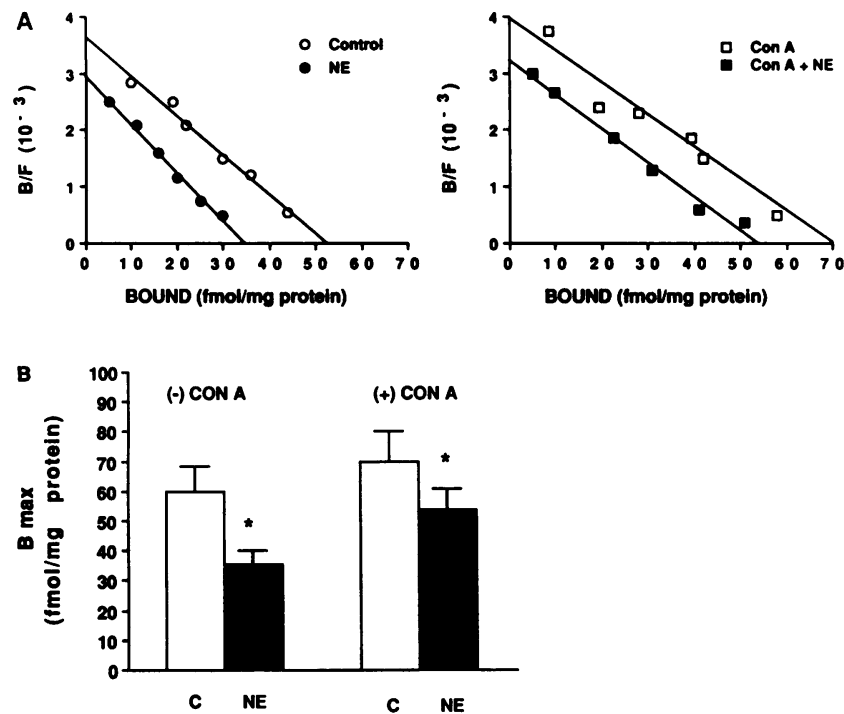

Figure 1. (A) Representative Scatchard plots obtained from neonatal rat ventricular myocytes treated with $\mathrm{NE}$ and Con $\mathrm{A}$. As can be seen in the left panel, incubation for $2 \mathrm{~h}$ with NE resulted in a $35 \%$ reduction in the number of cell surface binding sites assessed by ${ }^{3} \mathrm{H}-\mathrm{CGP}$ 12177. The right panel indicates that preincubation with $0.5 \mu \mathrm{g} / \mathrm{ml}$ Con $\mathrm{A}$ for $30 \mathrm{~min}$ increased the maximum number of binding sites and resulted in less downregulation after exposure to NE (26\%). (B) Data summary. 2-h incubation with $1 \mu \mathrm{M}(-)$-norepinephrine resulted in a $41 \%$ decline $(60.1 \pm 8.5$ to $35.6 \pm 4.5 \mathrm{fmol} / \mathrm{mg}$ protein $)$ in cell surface $\beta$-adrenergic receptor density assessed by ${ }^{3} \mathrm{H}$-CGP-12177 binding in intact ventricular myocytes (left). Preincubation with 0.5 $\mu \mathrm{g} / \mathrm{ml}$ Con A for 30 min attenuated the agonist-induced decline in $\beta$-adrenergic receptor density to $23 \%$ from $70.0 \pm 10$ to $54.0 \pm 6.7$ $\mathrm{fmol} / \mathrm{mg}$ protein (right). This difference in decline ( $23 \mathrm{vs.} 41 \%)$ was significant $(P<0.05)$. $C$, control; $B_{\max }$, maximum number of ${ }^{3} \mathrm{H}$ CGP-12177 binding sites. Values are mean $\pm \mathrm{SEM}, n=5$. *Statistical significance of $P<0.05$ vs. control.

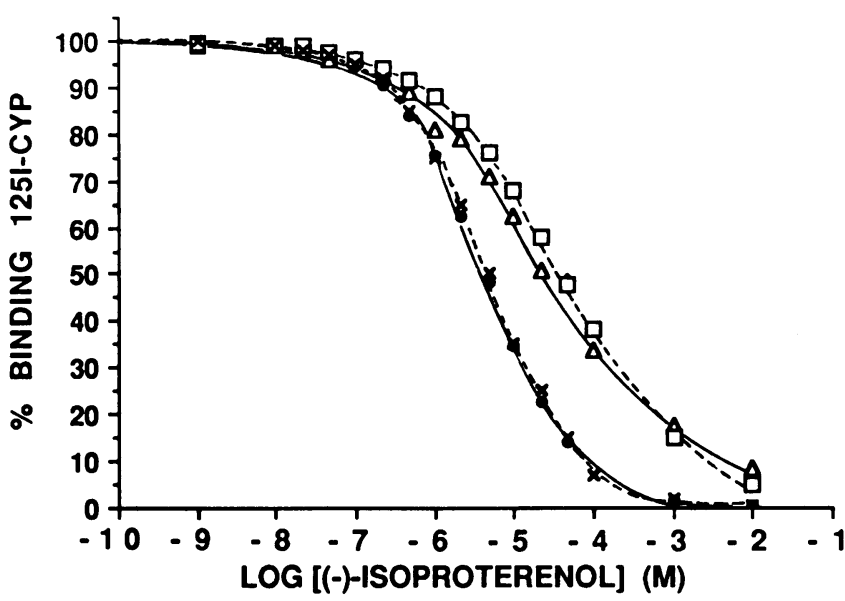

Figure 2. Competition curves with increasing concentrations of (-)isoproterenol ( $1 \mathrm{nM}-10 \mathrm{mM}$ ) coincubated with $20 \mathrm{pM}^{125} \mathrm{I}-\mathrm{ICYP}$ and membranes prepared from untreated myocytes $(X)$ and myocytes pretreated for $30 \mathrm{~min}$ with Con A ( filled circles). There is no effect of Con A on agonist- $\beta$-adrenergic receptor affinity. GTP $(100 \mu \mathrm{M})$ produced the expected rightward shift of the competition curve (open squares) which was unaltered by preincubation with Con A for 30 $\min (\Delta)$. Data represent the mean of three experiments, each performed in triplicate.

By contrast, agonist affinity for the $\beta$-adrenergic receptor as measured by (-)-isoproterenol competition was unaffected by Con A; furthermore, Con A had no effect on the GTP-mediated decrease in receptor affinity for agonist (Fig. 2).

To determine if the effects of Con A on $\beta$-adrenergic receptor downregulation were reversible, we used the selective lectin inhibitor methyl $\alpha$-D-mannopyranoside ( $\alpha$ MNP) (26). Cells were incubated either with Con A or NE and membranes prepared for equilibrium binding studies with ${ }^{125} \mathrm{I}-\mathrm{ICYP}$ as described under Methods. As expected, a 2-h incubation with 1 $\mu \mathrm{M}$ NE resulted in a $28 \%$ decline in $\beta$-adrenergic receptor density from $309 \pm 12$ to $221 \pm 16 \mathrm{fmol} / \mathrm{mg}$ protein $(n=7, P$ $<0.002)$. Preincubation with either $0.5 \mu \mathrm{g} / \mathrm{ml} \mathrm{Con} \mathrm{A}(n=6)$ or $100 \mathrm{mM} \alpha$-MNP for $30 \mathrm{~min}(n=4)$ had no significant effect on $\beta$-adrenergic receptor density. As noted in the experiments with ${ }^{3} \mathrm{H}$-CGP-12177, Con A prevented the decline in $\beta$-adrenergic receptor density produced by NE $(21$ vs. $1 \% ; n=3)$. In five experiments $\alpha$-MNP completely blocked the effect of Con $A$, with $\beta$-adrenergic receptor density declining in the presence of NE, $\alpha$-MNP, and Con A by $35 \%$ from $305 \pm 18$ to $198 \pm 13$ $\mathrm{fmol} / \mathrm{mg}$ protein $(P<0.004)$. None of the interventions described had any significant effect on antagonist $K_{\mathrm{d}}$ values which in control membranes averaged $79 \pm 10 \mathrm{pM}(n=7)$.

We then asked if the prevention of agonist-mediated downregulation by Con A was specific only for the $\beta$-adrenergic receptor. Incubation with $1 \mu \mathrm{M}$ of the muscarinic cholinergic agonist carbachol for $2 \mathrm{~h}$ reduced muscarinic receptor density assessed by ${ }^{3} \mathrm{H}$-methyl-scopolamine binding by $33 \%$ from $77.2 \pm 11.2$ to $51.6 \pm 10.1 \mathrm{fmol} / \mathrm{mg}$ protein $(P=0.04 ;$ Fig. 3 , left panel). Preincubation with Con A for $30 \mathrm{~min}$ also prevented this agonist-mediated receptor downregulation (Fig. 3, right panel).

Concanavalin A potentiates receptor-mediated agonist-stimulated cAMP accumulation in intact cardiac myocytes. Because Con A prevented agonist-induced $\beta$-adrenergic receptor 


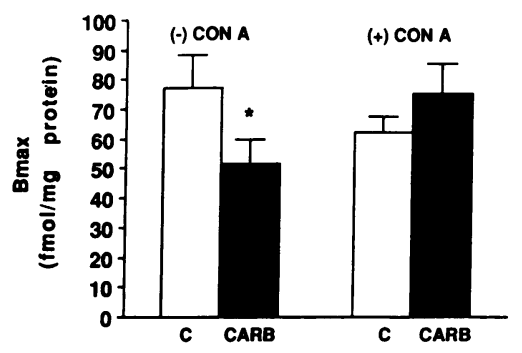
linergic receptor downregulation. Although $B_{\max }$ values in control cells were less after Con A pretreatment (open bars), this difference was not statistically significant. Con $A$ alone had no significant effect on $B_{\max }$ values. Data are mean \pm SEM for four experiments; ${ }^{*} P<0.05$; $C$, control; $C A R B$, carbachol; $B_{\max }$, maximum number of ${ }^{3} \mathrm{H}$ methyl-scopolamine binding sites.

downregulation, we next asked whether pretreatment with this agent would influence NE-stimulated cAMP accumulation. Cardiac myocytes were incubated with $0.5 \mu \mathrm{g} / \mathrm{ml} \mathrm{Con} \mathrm{A} \mathrm{for} 30$ min before a 5 -min stimulation by NE $(1 \mathrm{nM}-100 \mu \mathrm{M})$. As shown in Fig. 4, Con A preincubation increased agonist-stimulated cAMP generation in a dose-dependent manner. These experiments demonstrated that in addition to prevention of agonist-induced $\beta$-adrenergic receptor downregulation, Con $\mathrm{A}$ enhances receptor-mediated cAMP formation.

Concanavalin $A$ influences postreceptor regulation of cAMP. To determine whether Con A could likewise augment cAMP formation via a postreceptor mechanism, we incubated Con A-treated myocytes with the diterpene forskolin, which stimulates cAMP accumulation by interaction with the catalytic unit of adenylate cyclase (27) and likely in part by interaction with the stimulatory guanine nucleotide regulatory protein $\left(G_{s}\right)(28)$. As shown in Fig. 5, Con A pretreatment significantly increased 1 and $10 \mu \mathrm{M}$ forskolin-stimulated cAMP formation compared with control.

We then asked whether Con A interacts with the stimulatory GTP-binding protein $\mathrm{G}_{\mathrm{s}}$ in the absence of an effect on the catalytic subunit. Cholera toxin directly stimulates $G_{\mathbf{s}}$ by irreversible ADP-ribosylation of the $\alpha$-subunit and inhibits GTPase activity. Cardiac myocytes were preincubated for 30 min with Con A before exposure to $10 \mu \mathrm{g} / \mathrm{ml}$ of cholera toxin for 5 or $30 \mathrm{~min}$. In contrast to the enhancement of forskolin-

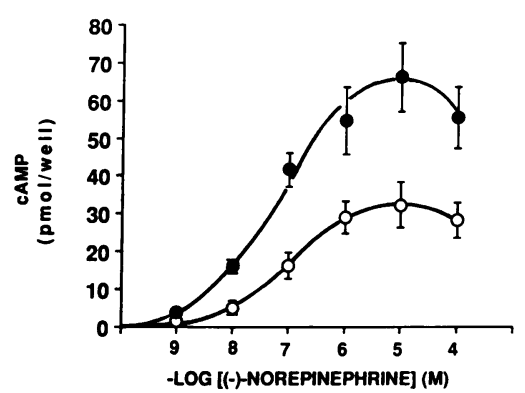

Figure 4. Dose-response curves produced after stimulation for $5 \mathrm{~min}$ with a range of $(-)$-norepinephrine concentrations ( $1 \mathrm{nM}$ to $100 \mu \mathrm{M})$ at $37^{\circ} \mathrm{C}$ in untreated myocytes (open circles) and in myocytes pretreated with Con A for 30 min (filled circles). Cyclic AMP levels are expressed as pmol/well. Myocytes were preincubated for $30 \mathrm{~min}$ in $1 \mathrm{mM}$ IBMX before stimulation. Con A preincubation did not alter basal cAMP levels ( $1.0 \pm 0.4$ vs. $1.1 \pm 0.35 \mathrm{pmol} /$ well). Each value represents the mean \pm SEM from four separate experiments.

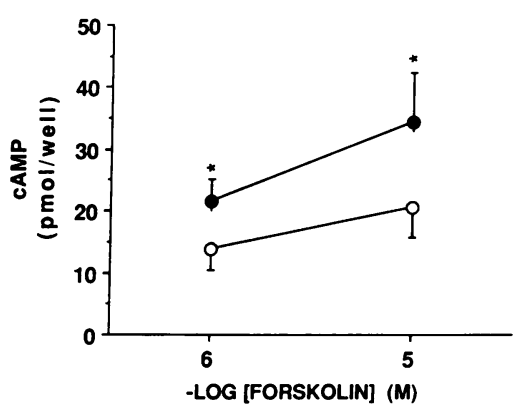

Figure 5. The effect of stimulation with forskolin $(1-10 \mu \mathrm{M})$ for $5 \mathrm{~min}$ on cAMP levels in untreated myocytes (open circles) and in myocytes pretreated for $30 \mathrm{~min}$ with Con A (closed circles). Con A preincubation did not alter basal cAMP levels $(1.3 \pm 0.2$ vs. $1.4 \pm 0.15 \mathrm{pmol} /$

well). Although the forskolin-stimulated levels in the absence of Con A (open circles) increased in a dose-dependent manner from $13.7 \pm 3.4$ to $20.5 \pm 4.7 \mathrm{pmol} /$ well after incubation with 1 and $10 \mu \mathrm{M}$ forskolin, respectively, this difference did not quite reach statistical significance $(P=0.07)$. By contrast, the forskolin-stimulated cAMP levels in the myocytes pretreated with Con A (closed circles) were significantly increased when 1 and $10 \mu \mathrm{M}$ forskolin were compared (21.5 3.5 vs. $34.2 \pm 8.1 \mathrm{pmol} /$ well; $P<0.05)$ ) ${ }^{*} P<0.05$ vs. the untreated control value; each value represents mean \pm SEM from five separate experiments.

stimulated cAMP synthesis, Con A did not alter cholera toxinstimulated cAMP accumulation at these time points (Table I). Using the method of Jones et al. (29), we permeabilized cells with $10 \mu \mathrm{M} / \mathrm{ml}$ saponin. Subsequent incubation with $0.5 \mu \mathrm{g} /$ $\mathrm{ml}$ Con A had no effect on the ability of $100 \mathrm{mM} \mathrm{GTP \gamma S}$ to augment cAMP accumulation ( $n=3-4$, data not shown). These observations, coupled with the data presented above, suggest that Con A augments cAMP generation both by receptor-mediated and postreceptor mechanisms; the latter appears to require involvement of the catalytic subunit of adenylate cyclase.

To investigate the potential importance of an intact cytoarchitecture to the augmentation of cAMP generation by Con A, membranes from myocytes preincubated in $0.5 \mu \mathrm{g} / \mathrm{ml}$ Con A for $30 \mathrm{~min}$ were prepared. Adenylate cyclase activity stimulated by $100 \mu \mathrm{M}$ forskolin in the presence and absence of varying concentrations of the nonhydrolyzable GTP analogue guanyl-5'-imidodiphosphate ( $\mathrm{Gpp}(\mathrm{NH}) \mathrm{p})$ was determined (Table II). In contrast to the data obtained in intact myocytes using measurements of CAMP, Con A pretreatment did not enhance

Table I. Effect of Concanavalin A on Cholera Toxin-stimulated cAMP Generation in Cultured Intact Neonatal Ventricular Myocytes

\begin{tabular}{lrr}
\hline & \multicolumn{2}{c}{ cAMP } \\
\cline { 2 - 3 } & \multicolumn{1}{c}{ Control } & Con A \\
\hline & & pmol/well \\
Basal & $0.9 \pm 0.3$ & $1.1 \pm 0.4$ \\
Cholera toxin $(5 \mathrm{~min})$ & $15.2 \pm 5.3$ & $17.9 \pm 6.3$ \\
Cholera toxin $(30 \mathrm{~min})$ & $25.2 \pm 7.9$ & $27.4 \pm 7.7$
\end{tabular}

Intact ventricular myocytes were preincubated with $10 \mu \mathrm{g} / \mathrm{ml}$ cholera toxin for 5 and $30 \mathrm{~min}$. Myocytes were preincubated with $1 \mathrm{mM}$ IBMX $/ 5 \%$ bovine calf serum for $30 \mathrm{~min}$ before cholera toxin exposure. All values are given as the mean $\pm \mathrm{SEM}, n=3, P=\mathrm{NS}$. 
Table II. Adenylate cyclase activity in ventricular myocyte membranes

\begin{tabular}{|c|c|c|c|}
\hline & Control & Con $\mathrm{A}$ & $P$ value \\
\hline & \multicolumn{2}{|c|}{ pmol cAMP/mg protein $/ 30 \mathrm{~min}$} & \\
\hline Forskolin $(100 \mu \mathrm{M})$ & $57.5 \pm 12.1$ & $60.1 \pm 17.3$ & NS \\
\hline Gpp(NH)p $(100 \mu \mathrm{M})$ & $53.6 \pm 12.5$ & $66.2 \pm 17.0$ & NS \\
\hline $\mathrm{Gpp}(\mathrm{NH}) \mathrm{p}(600 \mu \mathrm{M})$ & $51.0 \pm 21.3$ & $52.2 \pm 14.0$ & NS \\
\hline $\mathrm{G}(100 \mu \mathrm{M})+\mathrm{F}(100 \mu \mathrm{M})$ & $146.2 \pm 54.0$ & $155.1 \pm 52.9$ & NS \\
\hline $\mathrm{G}(600 \mu \mathrm{M})+\mathrm{F}(100 \mu \mathrm{M})$ & $113.4 \pm 36.9$ & $124.3 \pm 41.8$ & NS \\
\hline Gpp(NH)p (50 nM) & $7.4 \pm 1.8$ & $8.4 \pm 3.0$ & NS \\
\hline $\mathrm{G}(50 \mathrm{nM})+$ Iso (1 nM) & $11.0 \pm 3.1$ & $12.2 \pm 4.0$ & NS \\
\hline $\mathrm{G}(50 \mathrm{nM})+$ Iso (10 nM) & $12.2 \pm 2.1$ & $14.7 \pm 3.3$ & NS \\
\hline $\mathrm{G}(50 \mathrm{nM})+$ Iso $(100 \mathrm{nM})$ & $15.3 \pm 4.0$ & $16.2 \pm 2.1$ & NS \\
\hline $\mathrm{G}(50 \mathrm{nM})+$ Iso $(1 \mu \mathrm{M})$ & $15.3 \pm 4.3$ & $15.2 \pm 3.3$ & NS \\
\hline $\mathrm{G}(50 \mathrm{nM})+$ Iso $(10 \mu \mathrm{M})$ & $14.8 \pm 3.0$ & $15.3 \pm 2.5$ & NS \\
\hline
\end{tabular}

Adenylate cyclase activity in cardiac membranes was measured in the presence of the indicated effectors. Data are presented as mean \pm SEM of three experiments. Con A-treated membranes were preincubated in Con A $(0.5 \mu \mathrm{g} / \mathrm{ml})$ for $2 \mathrm{~h}$ before assay (see Methods). All data shown are minus basal values which averaged $16.7 \mathrm{pmol}$ cAMP/mg protein/30 min and did not differ significantly between control and Con A-treated membranes or forskolin/Gpp(NH)p experiments using method No. 1 (see Methods) (top). In the lower panel, adenylate cyclase activity was assayed using method No. 2 (see Methods). Data shown are minus basal values which averaged $0.025 \mathrm{pmol}$ cAMP $/ \mathrm{mg}$ protein/30 min and did not significantly differ between control and Con A-treated membranes. Iso, isoproterenol; $G, G p p(N H) p ; F$, forskolin.

forskolin-stimulated adenylate cyclase activity in membranes. These data suggest that preservation of intact membrane and intracellular spatial relations is required for Con A to augment the synthesis of CAMP.

We then investigated the possible interaction between Con $A$ and the regulation of cAMP via the pathway that utilizes the inhibitory guanine nucleotide protein, $G_{i}$. As expected, incubation with the muscarinic cholinergic receptor agonist carbachol (1-100 $\mu \mathrm{M})$ decreased cAMP stimulated by $1 \mu \mathrm{M}$ NE in intact myocytes (Fig. 6). To our surprise, however, $30 \mathrm{~min}$ of treatment with Con A before simultaneous addition of carba-

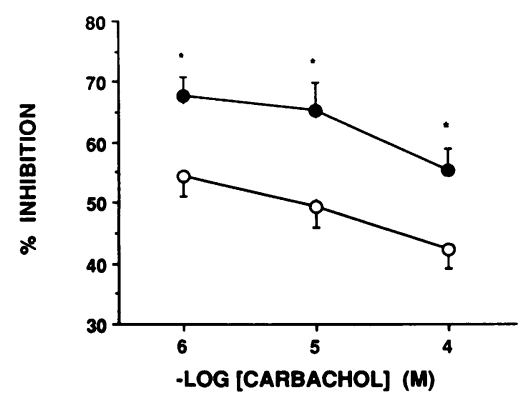

Figure 6. The effect of carbachol $(1-100 \mu \mathrm{M})$ on stimulation with 1 $\mu \mathrm{M}(-)$-norepinephrine for $5 \mathrm{~min}$ in untreated myocytes (open circles) and in myocytes pretreated for 30 min with Con A ( filled circles). Data are expressed as percentage inhibition of the maximum

amount of cAMP produced after stimulation with $1 \mu \mathrm{M}(-)$-norepinephrine for $5 \mathrm{~min}$ which averaged $27.9 \pm 4.3 \mathrm{pmol} /$ well; results represent mean percentage inhibition \pm SEM from seven separate experiments; ${ }^{*} P<0.05$. chol and NE augmented the inhibitory effect of carbachol on cAMP accumulation. This observation demonstrates that Con A also modulates inhibitory adenylate cyclase-linked pathways.

In light of these data we wondered whether we could detect any change in the ability of pertussis toxin to ADP-ribosylate $G_{i}$ after pretreatment with Con A. In two experiments, there was no effect on a 40-kD band observed on sodium dodecylsulfate polyacrylamide gel electrophoresis after incubation with ${ }^{32} \mathrm{P}-\mathrm{NAD}$ and $1 \mu \mathrm{g} / \mathrm{ml}$ pertussis toxin for $2 \mathrm{~h}$, when membranes from Con A-pretreated cells were compared with control membranes (data not shown).

\section{Discussion}

This present study is the first to investigate the effects of Con A on both stimulatory and inhibitory adenylate cyclase-linked pathways in cardiac myocytes. Our data demonstrate that Con A prevents both $\beta$-adrenergic and muscarinic cholinergic-induced receptor downregulation while amplifying agonist-mediated signal transduction. The effect of Con A on $\beta$-adrenergic receptor downregulation was blocked by a selective inhibitor of this lectin, methyl $\alpha$-D-methylmannopyranoside. Our observation that Con A prevents agonist-mediated $\beta$-adrenergic receptor downregulation is consistent with those of others in various cells (30-32). However, previous studies did not examine the effects of Con A on muscarinic cholinergic receptors or the influence of these agents on second messenger formation mediated by receptor and postreceptor pathways. A novel observation, not previously reported either in cardiac cells or to our knowledge in other systems, is that perturbation of the cell membrane by Con A results in either augmented inhibition or stimulation of cAMP synthesis, depending on the agonist employed. Thus Con A alters both stimulatory and inhibitory adenylate cyclase-linked pathways.

Both Waldo et al. (32) and Insel and Koachman (33) reported that adenylate cyclase activity did not increase in cell homogenates after incubation with Con A. Our inability to demonstrate enhanced receptor- (isoproterenol) and postreceptor- (forskolin) stimulated adenylate cyclase activity in homogenates prepared from cardiac myocytes preincubated with Con A (Table II) is in accord with these results and suggests that maintenance of an intact cytoarchitecture is a prerequisite for the enhancement of cAMP generation. Thus, our data are consistent with, but do not prove, the hypothesis that Con A may perturb plasma membrane-cytoskeletal spatial organization in intact neonatal ventricular myocytes, thereby amplifying transmembrane signal transduction.

Our investigations into the possible cellular locations mediating these altered responses suggest that Con A exerts its effect at multiple levels. The data also indicate that a major site of action is the $G$ protein-catalytic subunit complex. We noted that Con A does not affect $\beta$-adrenergic receptor affinity for (-)-isoproterenol, indicating that amplification of agoniststimulated cAMP generation is not the result of enhanced agonist-receptor coupling. Moreover, we observed that Con A pretreatment alone did not alter either $\beta$-adrenergic receptor or muscarinic cholinergic receptor density and did not affect either basal or cholera toxin-stimulated cAMP levels. In contrast to the lack of effect of cytochlasin B in S49 lymphoma cells 
(33), Con A pretreatment significantly enhanced cAMP accumulation in response to forskolin, an agent that activates the catalytic subunit of adenylate cyclase directly although it requires interaction with $\mathrm{G}_{\mathrm{s}}$ for full cAMP stimulation (28). The absence of a Con A effect on cholera toxin-stimulated cAMP levels and on cAMP accumulation stimulated by GTP $\gamma S$ in permeabilized myocytes suggests that the postreceptor target of Con $\mathrm{A}$ is the catalytic subunit of adenylate cyclase. Together, these data suggest that Con A not only prevents agonist-mediated $\beta$-adrengeric receptor downregulation but also alters interactions at levels beyond both the cell surface and agonist-receptor coupling.

Another possible mechanism of action of Con A is that it interferes with the normal interaction between protein kinase(s) and substrate(s). The role of protein kinases in the regulation of receptor-coupled transmembrane signaling is well established (for review see Sibley et al. [34]). These kinases may have attachments that directly modulate cytoskeletal activity $(15,35)$. In neonatal rat ventricular myocytes, the tumor-promoting phorbol ester 12-O-tetradecanoylphorbol-13-acetate (PMA) induces the transposition of protein kinase C (PKC) activity from a cytosolic to a membrane fraction (36) where it phosphorylates the $\beta$-adrenergic receptor and induces its downregulation (37). In rat C6 glioma cells Con A pretreatment prevents PMA-induced transposition of PKC activity from the cytosol to the plasma membrane (38). Recent evidence indicates that in neonatal rat ventricular myocytes, PMA induces translocation of a PKC isozyme to cytoskeletal elements (39). In recent experiments we found that $100 \mathrm{nM}$ PMA induced $\beta$-adrenergic receptor downregulation which was prevented by the protein kinase $C$ inhibitor H-7 (40). Additional experiments in neonatal rat ventricular myocytes indicate that Con A pretreatment prevents PMA-mediated $\beta$ adrenergic receptor downregulation (unpublished observations). These data are consistent with an effect of Con $\mathrm{A}$ at multiple levels in the control of signal transduction, including receptor cycling and phosphorylation and $G$ protein-catalytic unit interactions.

In summary, our data indicate that Con A influences signaling pathways mediated by the adenylate cyclase-muscarinic cholinergic receptor systems in neonatal rat ventricular myocytes. These observations are consistent with the hypothesis that interference with normal membrane-cytoskeletal interactions may perturb the spatial orientation of specific components of the receptor-effector coupling system, leading to alterations in transmembrane signaling. These observations represent further evidence of the complexity and diversity of mechanisms that modulate cellular responses to hormonal stimulation in cardiac myocytes.

\section{Acknowledgments}

Supported by grants from the Department of Veterans Affairs Research Service, the National Heart, Lung, and Blood Institute Program Project Grant HL-25847, United States Public Health Service Training Grant GM-07546, and the California Affiliate of the American Heart Association. Dr. Rocha-Singh is a recipient of a National Institutes of Health Individual National Research Service Award (HL-07507-02).

\section{References}

1. Stryer, L., and H. R. Bourne. 1986. G proteins: a family of signal transducers. Annu. Rev. Cell Biol. 2:391-419.
2. Sahyoun, N. E., H. LeVine, G. M. Hebon, R. K. Khouri, and P. Cuatrecasas. 1981. Evidence for cytoskeletal association of the adenylate cyclase system obtained by differential extraction of rat erythrocyte ghosts. Biochem. Biophys. Res. Commun. 101:1003-1010.

3. Eide, B., P. Gierschik, G. Milligan, I. Mullaney, C. Unson, P. Goldsmith, and A. Spiegel. 1987. GTP-binding proteins in brain and neutrophil are tethered to the plasma membrane via their amino termini. Biochem. Biophys. Res. Commun. 148:1398-1405.

4. Carlson, K. E., M. J. Woolkalis, M. G. Newhouse, and D. R. Manning. 1987. Fractionation of the $\beta$ subunit common to guanine nucleotide binding regulatory proteins with the cytoskeleton. Mol. Pharmacol. 30:463-468.

5. Cherksey, B. D., J. A. Zadunaisky, and R. B. Murphy. 1980. Cytoskeletal constraints of the $\beta$-adrenergic receptor in frog erythrocyte membrane. Proc. Natl. Acad. Sci. USA. 77:6401-6405.

6. Rasenick, M. M., P. J. Stein, and M. W. Bitensky. 1981. The regulatory subunit of adenylate cyclase interacts with cytoskeletal components. Nature (Lond.). 294:560-562.

7. Ash, J. F., D. Louvard, and S. J. Singer. 1977. Antibody-induced linkages of plasma membrane to intracellular actomyosin-containing filaments in cultured fibroblasts. Proc. Natl. Acad. Sci. USA. 74:5584-5588.

8. Mescher, M. F., M. J. L. Jose, and S. P. Balk. 1981. Actin-containing matrix associated with the plasma membrane of murine tumour and lymphoid cells. Nature (Lond.). 289:139-144.

9. Iwasa, Y., and M. M. Hosey. 1984. Phosphorylation of cardiac sarcolemma proteins by the calcium-activated phospholipid-dependent protein kinase C. $J$. Biol. Chem. 259:534-540.

10. Benovic, J. L., L. J. Pike, R. A. Cerione, C. Staniszewski, T. Yoshimasa, J. Codina, M. G. Caron, and R. J. Lefkowitz. 1985. Phosphorylation of the mammalian $\beta$-adrenergic receptors by cyclic AMP-dependent protein kinase. Regulation of the rate of receptor phosphorylation and dephosphorylation by agonist occupancy and effects on coupling of the receptor to the stimulatory guanine nucleotide regulatory protein receptor. J. Biol. Chem. 260:7094-7102.

11. Kwatra, M. M., and M. M. Hosey. 1986. Phosphorylation of the cardiac muscarinic receptor in intact chick heart and its regulation by a muscarinic agonist. J. Biol. Chem. 261:12429-12432.

12. Leeb-Lundberg, L. M. F., S. Cotecchia, J. W. Lomasney, J. F. DeBernardis, R. J. Lefkowitz, and M. G. Caron. 1985. Phorbol esters promote $\alpha_{1}$-adrenergic receptor phosphorylation and receptor uncoupling from inositol phospholipid metabolism. Proc. Natl. Acad. Sci. USA. 82:5651-5655.

13. Bouvier, M., L. M. F. Leeb-Lundberg, J. L. Benovic, M. C. Caron, and R. J. Lefkowitz. 1987. Regulation of adrenergic receptor function by phosphorylation. II. Effect of agonist occupancy on phosphorylation of $\alpha_{1}$ - and $\beta$-adrenergic receptors by protein kinase $C$ and the cyclic AMP-dependent protein kinase. $J$. Biol. Chem. 262:3106-3113.

14. Geiger, B. 1983. Membrane-cytoskeletal interactions. Biochim. Biophys. Acta. 737:305-341.

15. Burn, P., A. Kuffer, and S. J. Singer. 1988. Dynamic membrane-cytoskeletal interactions: specific associations of integrin and talin arises in vivo after phorbol ester treatment of peripheral blood lymphocytes. Proc. Natl. Acad. Sci. USA. 85:497-501.

16. Reeke, G. N., J. W. Becker, B. A. Cunningham, G. R. Gunter, J. L. Wang and G. M. Edelman. 1974. Relationships between the structure and activities of concanavalin A. Ann. NY Acad. Sci. 234:369-382.

17. Nicolson, G. L. 1976. Lectins as structural probes. IV. Biochim. Biophys. Acta. 457:116-133.

18. Nakajima, M., E. Tamura, T. Irimura, S. Toyoshima, H. Hirano, and T. Osawa. 1981. Mechanisms of the concanavalin A-induced change of membrane fluidity of chicken erythrocytes. J. Biochem. 89:665-675.

19. Simpson, P., and S. Savion. 1982. Differentiation of rat myocytes in single cell culture with and without proliferating nonmyocardial cells: cross striations, ultrastructure, and chronotropic response to isoproterenol. Circ. Res. 50:101116.

20. Karliner, J. S., P. C. Simpson, N. Honbo, and W. Woloszyn. 1986. Mechanisms and time course of beta $a_{1}$-adrenoceptor desensitisation in mammalian cardiac myocytes. Cardiovasc. Res. 20:221-228.

21. Scatchard, G. 1949. The attraction of proteins for small molecules and ions. Ann. NY Acad. Sci. 51:660-672.

22. Lowry, O. H., N. J. Rosenbrough, A. L. Farr, and R. J. Randall. 1951. Protein measurement with the Folin phenol reagent. J. Biol. Chem. 265:265-275.

23. Ramachandran, J. 1971. A new simple method for separation of adenosine 3',5'-cyclic monophosphate from other nucleotides and its use in the assay of adenyl cyclase. Anal. Biochem. 43:227-239.

24. Karliner, J. S., M. B. Stevens, N. Honbo, and J. I. E. Hoffman. 1989. Effects of acute ischemia in the dog on myocyardial blood flow, beta receptors, and adenylate cyclase activity with and without chronic beta blockade. J. Clin. Invest. 83:474-481.

24a. Alvarez, R., and D. V. Daniels. A single column method for the assay of adenylate cyclase. 1990. Anal. Biochem. 187:98-103. 
25. Steiner, A. L., C. W. Parker, and D. M. Kipnis. 1972. Radioimmunoassay for cyclic nucleotides. J. Biol. Chem. 247:1106-1113.

26. Kammer, K., and M. M. Burger. 1983. Release of cell-associated concanavalin A by methyl $\alpha$-D-mannopyranoside reveals three binding states of concanavalin-A receptors on mouse fibroblasts. Eur. J. Biochem. 132:433-439.

27. Seamon, K., and J. W. Daly. 1981. Activation of adenylate cyclase by the diterpene forskolin does not require the nucleotide regulatory protein. $J$. Biol. Chem. 256:9799-9801.

28. Darfler, F. J., L. C. Mahan, A. M. Koachman, and P. A. Insel. 1982 Stimulation by forskolin of intact $\$ 49$ lymphoma cells involves the nucleotide regulatory protein of adenylate cyclase. J. Biol. Chem. 257:11901-11907.

29. Jones, L. G., D. Goldstein, and J. H. Brown. 1988. Guanine nucleotidedependent inositol trisphosphate formation in chick heart cells. Circ. Res 62:299-305.

30. Limas, C. J., and C. Limas. 1983. Involvement of microtubules in the isoproterenol-induced 'down'-regulation of myocardial $\beta$-adrenergic receptors. Biochim. Biophys. Acta 735:181-184.

31. Marsh, J. D., D. Lachance, and D. Kim. 1985. Mechanisms of $\beta$-adrenergic regulation in cultured chick heart cells. Role of cytoskeletal function and protein synthesis. Circ. Res. 57:171-181.

32. Waldo, G. L., J. K. Northup, J. P. Perkins, and T. K. Harden. 1983 Characterization of an altered membrane form of the $\beta$-adrenergic receptor produced during agonist-induced desensitization. J. Biol. Chem. 258:13900-13908.

33. Insel, P. A., and A. M. Koachman. 1982. Cytochalasin B enhances hor- mone and cholera toxin-stimulated cyclic AMP accumulation in S49 lymphoma cells. J. Biol. Chem. 257:9717-9723.

34. Sibley, D. R., J. L. Benovic, M. G. Caron, and R. J. Lefkowitz. 1987 Regulation of transmembrane signaling by receptor phosphorylation. Cell. 48:913-922.

35. Osawa, S., and P. Hall. 1985. Adenosine 3',5'-monophosphate-dependent protein kinase associated with the cytoskeleton of adrenal tumor cells. Endocrinology 117:2347-2355.

36. Henrich, C. J., and P. C. Simpson. 1989. Differential acute and chronic response of protein kinase $\mathrm{C}$ in cultured neonatal rat heart myocytes to $\alpha_{1}$-adrenergic and phorbol ester stimulation. J. Mol. Cell. Card. 20:1081-1085.

37. Kassis, S., T. Zaremba, J. Patel, and P. H. Fishman. 1985. Phorbol esters and $\beta$-adrenergic agonists mediate desensitization of adenylate cyclase in rat glioma C6 cells by distinct mechanisms. J. Biol. Chem. 260:8911-8917.

38. Patel, J., and S. Kassis. 1987. Concanavalin A prevents phorbol-mediated redistribution of protein kinase $C$ and $\beta$-adrenergic receptors in rat glioma C6 cells. Biochem. Biophys. Res. Commun. 144:1265-1272.

39. Mochly-Rosen, D., C. J. Henrich, L. Cheever, H. Khaner, and P. C. Simpson. 1990. A protein kinase C isozyme is translocated to cytoskeletal elements on activation. Cell Regulation 1:693-706.

40. Reupcke, C., N. Honbo, and J. S. Karliner. 1988. Phorbol ester down-regulates $\beta$-adrenergic receptors but results in enhanced cAMP production in neonatal rat ventricular myocytes: possible role for protein kinase $\mathrm{C}$ in the regulation of cAMP. Clin. Res. 36:310A. 